\title{
Antibacterial activity of lysozyme in the desert locust, Schistocerca gregaria (Orthoptera: Acrididae)
}

\author{
Amr A. MOHAMED ${ }^{1}$, Mohamed ELMOGY ${ }^{1,2}$, Moataza A. DORRAH ${ }^{1}$, Hesham A. YOUSEF $^{1}$ \\ and TAHA T.M. BASSAL ${ }^{1 *}$ \\ ${ }^{1}$ Department of Entomology, Faculty of Science, Cairo University, Giza, Egypt; e-mails: mamr@sci.cu.edu.eg; \\ elmoogy@yahoo.com; moatazaahmed@gmail.com; heshamyousef.eg@gmail.com \\ ${ }^{2}$ Department of Biology, Faculty of Applied Science, Um AlQura University, Mecca, Saudi Arabia
}

Key words. Orthoptera, Acrididae, Schistocerca gregaria, antibacterial, lysozyme, Escherichia coli, haemocytes

\begin{abstract}
The ability of biocontrol agents to overcome the immune defense of pests is a crucial issue. This is the first study of lysozyme activity as an inducible humoral component of the defense of Schistocerca gregaria, which depends on the recognition of the elicitor molecules of pathogens and not on epidermal wounding or a spiking effect. The level of lysozyme activity in fat body, haemocytes and haemolymph plasma of naïve and immunologically challenged $5^{\text {th }}$ instar $S$. gregaria was evaluated using the zone of inhibition test against Micrococcus lysodeikticus. Various Gram-positive and Gram-negative bacteria as well as peptidoglycans (PGN) and lipopolysacchrides (LPS) of bacterial cell walls induce and increase in the level of lysozyme activity. Escherichia coli induced an increase in the level of activity of lysozyme in the fat body, haemocytes and plasma, but not in mid gut epithelium, 6-12 $\mathrm{h}$ after an immunological challenge and then it decreased to the constitutive level after $72 \mathrm{~h}$. This study revealed that in $S$. gregaria there is a constitutive and a bacteria-inducible level of lysozyme activity, which protects it against infection by both Gram-negative and Gram-positive bacteria.
\end{abstract}

\section{INTRODUCTION}

Insects lack an adaptive (acquired) immune system. They have an innate immune system that relies on germline encoded factors recognizing and killing foreign invaders, which effectively and rapidly protects them from infection caused by microorganisms and parasites (Tsakas \& Marmaras, 2010). This system is highly developed and comprises cellular and humoral components that can be activated by the invasion of foreign bodies, including pathogens (Gillespie et al., 1997). Recognition by the host of pathogen-associated molecular patterns triggers signaling cascades, which activate immune cells and the transcription of antimicrobial peptides that trap or kill pathogens (Marmaras \& Lampropoulou, 2009).

Lysozyme (E.C. 3.2.1.17) is one of the antimicrobial proteins with which insects respond to bacterial challenge (Jiang et al., 2011). Lysozymes are of several classes (Callewaert \& Michiels, 2010) and have a muramidase activity, i.e. they are able to hydrolyse the $\beta$-1,4-glycosidic linkage between the alternating linked residues of $\mathrm{N}$-acetylmuramic acid (MurNAc) and $\mathrm{N}$-acetylglucosamine (GlcNAc) of peptidoglycans, the major bacterial cell wall polymer, resulting in its lysis (Vocadlo et al., 2001). They are widely spread throughout nature; occurring in insects, vertebrates, plants and microorganisms (Jollès \& Jollès, 1984). Lysozymes generally exhibit greater antibacterial activity against Grampositive than Gram-negative bacteria (Wang et al., 2009). Some insect lysozymes also exhibit antifungal activity.
They hydrolyze the $\beta$-1,4-linkages of chitooligosaccharides in the fungal cell wall (Fiolka et al., 2005).

Both haemocytes and fat body, but primarily the latter, of various insects are reported to synthesize and release lysozymes into haemolymph (Lemaitre \& Hoffmann, 2007). However, other tissues, such as epidermis, muscles and mid gut cells may also participate in lysozymes production (Lee \& Brey, 1995; Hultmark, 1996). In Manduca sexta mid gut cells lysozymes are developmentally regulated independently of a bacterial infection (Russell \& Dunn, 1991).

The pest in this study, S. gregaria (Forskål) (Orthoptera: Acrididae), like other locusts and grasshoppers, is abundant in dry grassland and desert (Lomer et al., 2001), and is the most damaging of the locusts (Lecoq, 2004). Microbial control measures coupled with immunosuppressive agents are needed as part of a control program for this pest.

To our knowledge, unlike for the well-studied holometabolous insects, there is little information on lysozyme as an inducible humoral component of the defense mechanisms in hemimetabolous insects, particularly the orthopteroids (Hoffmann \& Brehelin, 1976; Hoffmann, 1980; Zachary \& Hoffmann, 1984; Schneider, 1985; Adamo, 2004; Adamo et al., 2008; Srygley \& Lorch, 2011). In locusts, the only known antimicrobial peptide (AMP) other than lysozyme is locustin (Swiss-Prot: P83428.1). Therefore, the aim of the present study is to estimate the antimicrobial activity of lysozyme in the plasma of naïve and bacterially challenged $5^{\text {th }}$ instar $S$. gregaria, identify

\footnotetext{
* Corresponding author; e-mail: tahabasal@gmail.com
} 
the tissues where lysozyme is produced and clarify the time course in the change in activity of lysozyme.

\section{MATERIAL AND METHODS}

\section{Insect rearing}

The $5^{\text {th }}$ instar nymphs of $S$. gregaria were obtained from a well-established laboratory colony at the Entomology Department, Faculty of Science, Cairo University, Egypt. There is a detailed description of this $S$. gregaria colony and the rearing technique in Maeno \& Tanaka (2008). We used $5^{\text {th }}$ instar individuals because the immature stages of insects frequently become infected during the moulting process and in the insect studied the $5^{\text {th }}$ instar is the last nymphal instar prior to radical changes in the body, involving histogenesis and organogeny of the adult body.

\section{Bacterial strains, culture and immune challenge}

The bacteria, Escherichia coli JM109 (Fermentas, Canada), Micrococcus luteus (ATCC 49732) (Biomerieux, Canada), Neisseria gonorrhoeae (ATCC 19424) and Staphylococcus aureus (ATCC 12600) were inoculated into sterile Luria-Bertani (LB) broth ( $1 \%$ tryptone (lab m, UK), $0.5 \%$ yeast extract (Oxoid, UK), $1 \% \mathrm{NaCl} w / \mathrm{v} ; \mathrm{pH} 7.2$ ). Pseudomonas aeruginosa (ATCC 10145) and Bacillus subtilis (ATCC 6051) were inoculated into sterile nutrient broth $[1 \%$ peptone (Difco, USA), $1 \%$ beef extract (Difco) and $0.5 \% \mathrm{NaCl} w / \mathrm{v}, \mathrm{pH} 7.2]$. Strains were grown overnight at $37^{\circ} \mathrm{C}$. Bacteria were obtained, unless otherwise indicated, from the Microbiology Division, Microanalytical Center, Cairo University, Egypt.

Before the immunological challenge, the bacterial cells were pelleted by centrifugation at $2000 \mathrm{~g}$ for $10 \mathrm{~min}$ at $4{ }^{\circ} \mathrm{C}$ and well washed with sterile Ringer's solution (113.7 mM NaCl, $1.9 \mathrm{mM}$ $\mathrm{KCl}, 1.1 \mathrm{mM} \mathrm{CaCl}_{2}, 0.12 \mathrm{mM} \mathrm{NaHCO}_{3}, 0.07 \mathrm{mM} \mathrm{Na}_{2} \mathrm{HPO}_{4}$; $\mathrm{pH}$ 7.2) using centrifugation. The cells were pelleted and resuspended in sterile Ringer's solution. The cell concentration was adjusted to give a final concentration of $6 \times 10^{4}$ cells $/ \mathrm{ml}$ and then immediately used in the experiments.

Fifth-instar $S$. gregaria, at mid-stadium age (day 5-7), were each injected with $20 \mu 1$ of log-phase bacteria between the $2^{\text {nd }}$ and $3^{\text {rd }}$ abdominal sclerites. Gram-positive B. subtilis, M. luteus and $S$. aureus, and the Gram-negative E. coli, N. gonorrhoeae and $P$. aeruginosa were used in this study. Also, nymphs were immunologically challenged by injection of $20 \mu \mathrm{g} / \mathrm{nymph}$ of bacterial or fungal cell wall components (purchased from Sigma-Aldrich, unless otherwise indicated) like lipopolysaccharide (LPS) from Salmonella enterica serotype abortus equi [prepared by the PCP method of Galanos et al. (1979)], Laminarin from Laminaria digitata, soluble peptidoglycan (PGN) from $S$. aureus, chitin (from shrimp shells), muramic acid and glucosamine.

\section{Collection and preparation of haemolymph and fat body and} mid gut tissue

Haemolymph was obtained by puncturing the arthrodial membrane in the hind legs of naïve or immunologically challenged chilled nymphs with a sterile needle and the haemolymph collected in ice-cold tubes containing a few crystals of phenylthiourea (Fluka). To determine the time course activity of lysozyme, haemolymph was collected immediately after (control) or at different intervals $(2,4,6,12,18,24,48$, and $72 \mathrm{~h})$ post-injection (immunologically challenged individuals). For each interval, haemolymph from 12 nymphs was pooled and used for measuring lysozyme activity (see below); each measurement was repeated 3 times. Plasma was obtained by centrifugation of haemolymph at $8000 \mathrm{~g}$ for $5 \mathrm{~min}$ at $4^{\circ} \mathrm{C}$ and stored at $-20^{\circ} \mathrm{C}$ until used.
For preparation of haemocyte lysate supernatant, haemolymph from 25 nymphs per treatment (naïve; saline- or E. coli injected) was collected immediately after (control) or $6 \mathrm{~h}$ post injection (treated) and gently mixed with $300 \mu \mathrm{l}$ ice-cold anticoagulant ( $62 \mathrm{mM} \mathrm{NaCl}, 100 \mathrm{mM}$ glucose, $10 \mathrm{mM}$ EDTA, $30 \mathrm{mM}$ trisodium citrate and $26 \mathrm{mM}$ citric acid, $\mathrm{pH} 4.6$ ). The haemolymph was centrifuged at $8000 \mathrm{~g}$ for $5 \mathrm{~min}$ at $4^{\circ} \mathrm{C}$. Pellets of haemocytes were washed twice with $500 \mu 1$ of Ringer's solution and then re-suspended in $50 \mu \mathrm{l}$ of lysis buffer $(20 \mathrm{mM}$ Tris- $\mathrm{HCl}$, $137 \mathrm{mM} \mathrm{NaCl}, 2$ mM EDTA, 0.1\% Triton-X 100, 10\% glycerol, $\mathrm{pH}$ 7.2). Haemocyte lysates were ultrasonicated for 1 min continuous pulse on ice and the cell debris removed by centrifugation at $10,000 \mathrm{~g}$ for $2 \mathrm{~min}$ at $4^{\circ} \mathrm{C}$. The haemocyte lysate supernatant (HLS) was stored in aliquots at $-20^{\circ} \mathrm{C}$ until used.

The level of induced lysozyme activity in different tissues was also compared quantitatively at 6, 12, 24, 48 and $72 \mathrm{~h}$. Fat body and mid gut epithelium were collected and washed with $0.01 \mathrm{M}$ sodium phosphate buffer $(\mathrm{pH}$ 7.0) and separately homogenized in $0.01 \mathrm{M}$ sodium acetate buffer ( $\mathrm{pH} 6.0$ ) containing protease inhibitors (complete-protease inhibitor cocktail tablets; Roche). The supernatants, after centrifugation at $8000 \mathrm{~g}$ for $15 \mathrm{~min}$ at $4{ }^{\circ} \mathrm{C}$, were used for assaying lysozyme activity. The activity was corrected for tissue protein content, i.e. values were obtained by dividing activity by total protein. The concentration of protein was estimated (Bradford, 1976) using bovine serum albumin as a standard. Controls were: (i) not injected [naïve control], (ii) injected with sterile saline or Ringer's solution, and (iii) wounded by piercing the cuticle of the abdomen.

\section{Determination of lysozyme activity using zone of inhibition test}

Lysozyme activity was determined using a slightly modified form of the zone of inhibition test (Zachary \& Hoffmann, 1984). Briefly, $5 \mu \mathrm{l}$ of crude plasma or tissue aliquots were placed into $3 \mathrm{~mm}$ wells punched in $1 \%$ agarose plates. The plates were inoculated with $1 \mathrm{mg}$ lyophilised M. lysodeikticus (ATCC 4698) cells (Sigma-Aldrich) per $\mathrm{ml}$ agarose. The activity was recorded by measuring the diameter $(\mathrm{mm})$ of the clear zone after incubating the plates for $24-48 \mathrm{~h}$ at $37^{\circ} \mathrm{C}$. The linear relationship between the diameter of the clear zone and the concentrations of a reference lysozyme, hen egg white lysozyme (HEWL) (Sigma-Aldrich, 40000 units $/ \mathrm{mg}$ ) was established and used as a reference for expressing the activity of the different samples in terms of $\mu \mathrm{g}$ HEWL.

\section{Statistical analyses}

The time course of the activity of lysozyme in different tissues was analyzed using a one way analysis of variance (ANOVA). Duncan test was used to determine the homogeneity of the means. Statistical analysis was performed using SPSS software (version 15; SPSS, Chicago, IL). Data are expressed as means \pm SD.

\section{RESULTS AND DISCUSSION}

\section{Constitutive lysozyme activity}

From the standard curve (Fig. 1), the diameter of the clear zone, which ranges from 5 to $14 \mathrm{~mm}$, is proportional to the logarithm of enzyme concentration, as previously described (Boman, 1994). The coefficient of determination, $\mathrm{R}^{2}$, of 0.99 of this relationship indicates this assay gives accurately reproducible results.

The activity of lysozyme in the pooled sample of haemolymph plasma of the insect used in this study, as in other studies, is considered to be an accurate measure of its titer in the whole insect body. This is because haemo- 


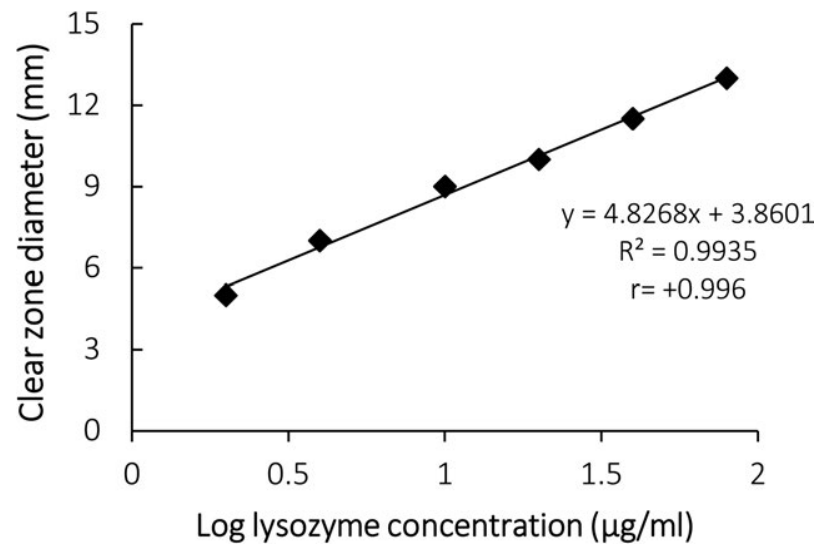

Fig. 1. The relationship between the activities of lysozyme recorded using the zone of inhibition test and the logarithm of the concentration of lysozyme.

lymph circulates throughout an insect's body and therefore where the lysozyme is most likely to collect after release from the tissues in which it is synthesized. Table 1 gives the constitutive level of lysozyme activity in the haemolymph plasma of naïve $5^{\text {th }}$ instar $S$. gregaria as about $80 \mu \mathrm{g}$ of HEWL $/ \mathrm{ml}$. This is similar to that recorded in the hemolymph of several hemimetabolous [Locusta migratoria (Zachary \& Hoffmann, 1984) and Gryllus bimaculatus (Schneider, 1985)] and holometabolous [Apis mellifera (Mohrig \& Messner, 1968), Galleria mellonella (Powning \& Davidson, 1973; Fiolka, 2012), Spodoptera eridania (Anderson \& Cook, 1979), Bombyx mori (Morishima et al., 1995), and Samia cynthia ricini
(Fujimoto et al., 2001)] insects. This value is considered to be the background level of activity and the initial immune response to invading microorganisms. For instance, it is believed to degrade the bacterial debris released during the initial cellular immune response (Park et al., 1997).

Sequential immune responses, such as the synthesis and secretion of lysozymes and other antimicrobial peptides, are thought to be elicited by PGN fragments resulting from the lysis of microbes (Kaneko et al., 2004; Park et al., 2007). This is thought to be a key-step in pattern recognition, which is followed by transduction of signals and initiation of antimicrobial responses (Tsakas \& Marmaras, 2010).

\section{Induced lysozyme}

Inducers and induction

The activity of lysozyme in the body of a $5^{\text {th }}$ instar $S$. gregaria was elevated by injecting certain elicitors into its haemocoel. These elicitors (Table 1) included whole cells (of log phase) of different Gram-positive and Gramnegative bacteria, or certain components of bacterial or fungal cell-walls. The level of the induced lysozyme activity in haemolymph plasma of immunized nymphs is significantly dependent on the elicitor used (Table 1).

Firstly, the level of lysozyme activity induced by whole bacterial cells depends on the species of bacteria. For $E$. coli, in particular, the proportionality test indicates that there is a positive linear correlation between the induction of lysozyme activity and doses of up to 800 bacterial cells/nymph and then it remains fairly constant (Fig. 2).

TABLE 1. Levels of haemolymph ${ }^{\mathrm{a}}$ lysozyme lytic activity ${ }^{\mathrm{b}}$ recorded in $5^{\text {th }}$ instar $S$. gregaria induced by different species of bacteria, their cell wall components and non-microbial sugars. Activity was assessed using zone of inhibition test against M. lysodeikticus.

\begin{tabular}{|c|c|}
\hline Inducer & Lytic activity $^{\mathrm{e}}(\mu \mathrm{g} / \mathrm{ml})$ \\
\hline Naïve insects & $76 \pm 6.48$ \\
\hline Saline & $81 \pm 10.22$ \\
\hline \multicolumn{2}{|l|}{ Gram-positive bacteriac: } \\
\hline B. subtilis ATCC 6051 & $162 \pm 22.58$ \\
\hline M. luteus ATCC 49732 & $104 \pm 15.01$ \\
\hline S. aureus ATCC 12600 & $218 \pm 16.91$ \\
\hline \multicolumn{2}{|l|}{ Gram-negative bacteria: } \\
\hline E. coli JM109 & $232 \pm 15.58$ \\
\hline N. gonorrhoeae ATCC 19424 & $132 \pm 9.48$ \\
\hline P. aeruginosa ATCC 10145 & $185 \pm 13.15$ \\
\hline \multicolumn{2}{|l|}{ Bacterial cell wall components ${ }^{\mathrm{d}}$ : } \\
\hline Peptidoglycan from $S$. aureus & $194 \pm 12.5$ \\
\hline LPS from Salmonella enteritica serotype abortus equi & $181 \pm 6.32$ \\
\hline Muramic acid & $77 \pm 7.34$ \\
\hline Glucosamine & $102 \pm 8.22$ \\
\hline Non-bacterial $\beta-1,3$ glucans: Laminarin from Laminaria digitata & $84 \pm 14.22$ \\
\hline Non-bacterial $\beta-1,4$ glucans: Chitin (undetermined chain-length) & $76 \pm 10.29$ \\
\hline
\end{tabular}

${ }^{\mathrm{a}}$ Haemolymph was sampled $6 \mathrm{~h}$ post-injection (the time of maximum activity); ${ }^{\mathrm{b}}$ lysozyme activity was measured in terms of $\mu \mathrm{g} / \mathrm{ml}$ of HEWL; ' injected 1200 cells in $20 \mu \mathrm{l}$ saline/nymph; ${ }^{\mathrm{d}}$ injected $10 \mu \mathrm{g}$ in $20 \mu \mathrm{l}$ saline/nymph; ${ }^{\mathrm{e}}$ each value is the mean $\pm \mathrm{SD}$ of the results of three different experiments $(\mathrm{n}=3)$. 


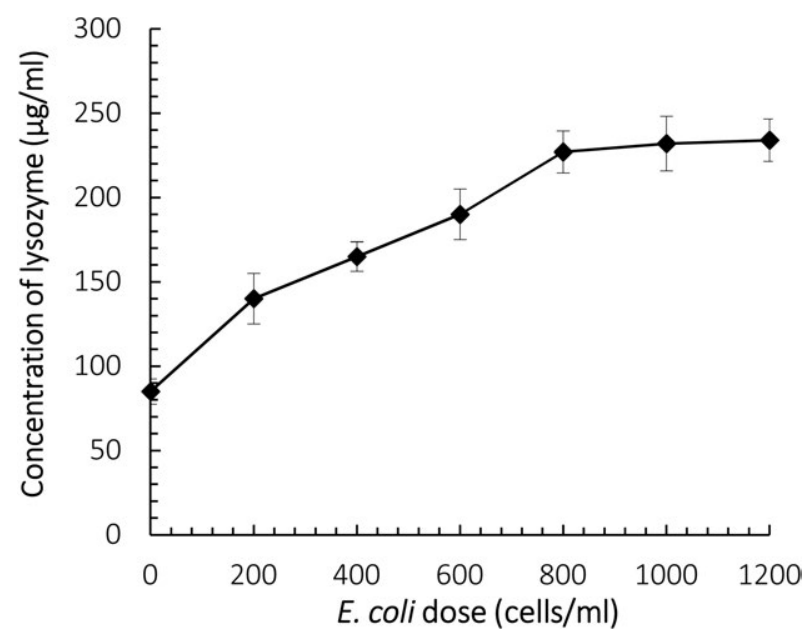

Fig. 2. The relationship between the activities of lysozyme in plasma of $5^{\text {th }}$ instar $S$. gregaria induced by the injection of different doses of $E$. coli contained in $20 \mu$ l of Ringer's solution.

This indicates that $E$. coli can elicit increased lysozyme activity in this insect. Therefore, in the present study, $E$. coli was used as a general elicitor of lysozyme activity. Similar dose-dependent inductions of lysozyme activity by $E$. coli are also reported in other insects, e.g. Spodoptera eridania (Anderson \& Cook, 1979), B. mori (Abraham et al., 1995) and Gryllus texensis (Adamo, 2004), and E. coli is also considered to be an effective inducer of insect humoral immune responses in general (Erler et al., 2011) and of hemolymph lysozyme activity, in particular, e.g. B. mori (Sumida et al., 1992; Abraham et al., 1995), Melanoplus sanguinipes (Gillespie et al., 1993), Artogeia rapae (Bang \& Yoe, 2005), S. frugiperda (Chapelle et al., 2009) and Anopheles gambiae (Kajla et al., 2010). Also, there is no clear-cut specificity in terms of pathogen recognition, signaling pathways, or effector molecules in the course of induction of humoral responses in insects (Marmaras \& Lamproulou, 2009).

Secondly, the macromolecules PGN and LPS in bacterial cell walls are shown to be strong inducers of lyso-

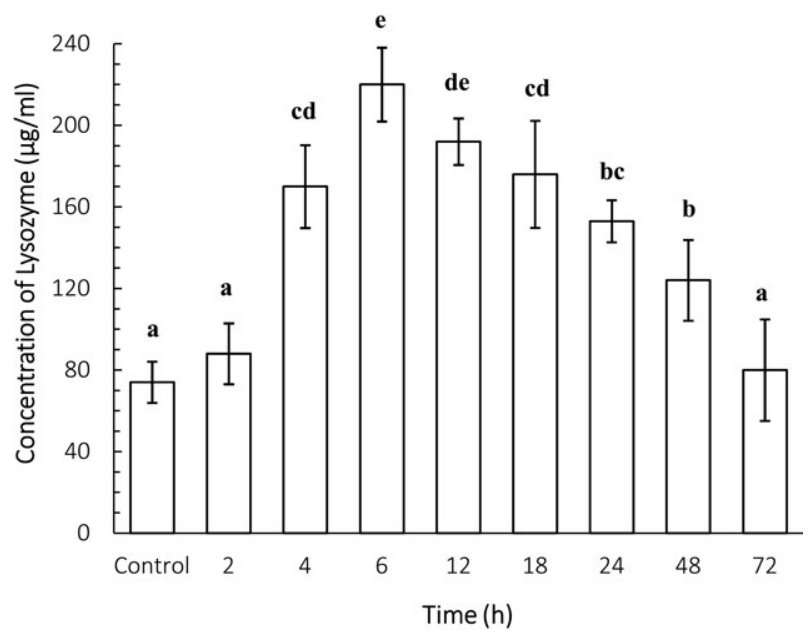

Fig. 3. The concentration of lysozyme recorded in injected and control $5^{\text {th }}$ instar $S$. gregaria at different times after injection with log-phase E. coli $\left(6 \times 10^{4}\right.$ cells in $20 \mu 1$ saline $)$. Bars marked with the same letters are similar (insignificantly different; $P>0.05$ ) whereas, those with different letters aren't (significantly different; $P<0.05$ ).

zyme activity in this hemimetabolous insect (Table 1). This has similarly been reported in holometabolous insects, e.g., PGN in M. sexta (Kanost et al., 1988), B. mori (Morishima et al., 1995) and S. cynthia ricini (Fujimoto et al., 2001), and LPS in S. eridania (Anderson \& Cook, 1979), Heliothis virescens (Shelby et al., 1998) and G. mellonella (Fiolka, 2012).

However, it is uncertain which of the molecular components of these conjugated carbohydrates (PGN and LPS) act as elicitors (Marmaras \& Lamproulou, 2009). The macromolecular fragments and even the muropeptides of PGN are reported (Kaneko et al., 2004; Park et al., 2007) to be elicitors of antimicrobial peptide synthesis and secretion. However, in the present study, molecules below this size, i.e. the mono sugar mother-molecules of PGN glucosamine and muramic acid did not elicit a response (Table 1). On the other hand, the inductive

TABLE 2. Lysozyme activity recorded in haemocytes, plasma, fat body and mid gut of naïve and $5^{\text {th }}$ instar $S$. gregaria that were injected with saline or E. coli, respectively. Lysozyme activity in plasma and haemocytes was measured after different intervals of time of 6 to $72 \mathrm{~h}$.

\begin{tabular}{|c|c|c|c|c|c|}
\hline \multirow{2}{*}{ Treatment: } & \multirow{2}{*}{$\begin{array}{l}\text { Time } \\
\text { (h) }\end{array}$} & \multicolumn{4}{|c|}{ Lysozyme activity ( $\mu \mathrm{g} / \mathrm{mg}$ protein)* } \\
\hline & & Haemocytes & Plasma & Fat body & Mid gut \\
\hline Naïve control & & $0.76 \pm 0.06^{\mathrm{a}}$ & $0.72 \pm 0.06^{\mathrm{a}}$ & $0.17 \pm 0.03^{\mathrm{a}}$ & -ve \\
\hline Saline injected & 6 & $0.91 \pm 0.08^{\mathrm{a}}$ & $0.76 \pm 0.09^{\mathrm{a}}$ & $0.15 \pm 0.04^{\mathrm{a}}$ & -ve \\
\hline E. coli & $\begin{array}{c}6 \\
12 \\
24 \\
48 \\
72\end{array}$ & $\begin{array}{l}3.74 \pm 0.18^{\mathrm{d}} \\
3.48 \pm 0.22^{\mathrm{d}} \\
2.12 \pm 0.25^{\mathrm{c}} \\
1.79 \pm 0.13^{\mathrm{b}} \\
0.82 \pm 0.12^{\mathrm{a}}\end{array}$ & $\begin{array}{l}2.05 \pm 0.14^{\mathrm{c}} \\
1.88 \pm 0.11^{\mathrm{c}} \\
1.44 \pm 0.07^{\mathrm{b}} \\
1.26 \pm 0.11^{\mathrm{b}} \\
0.74 \pm 0.13^{\mathrm{a}}\end{array}$ & $\begin{array}{c}0.45 \pm 0.06^{\mathrm{b}} \\
\text { ND } \\
\text { ND } \\
\text { ND } \\
0.14 \pm 0.04^{\mathrm{a}}\end{array}$ & $\begin{array}{l}\text {-ve } \\
\text { ND } \\
\text { ND } \\
\text { ND } \\
\text {-ve }\end{array}$ \\
\hline $\begin{array}{l}\text { Difference in the level of } \\
\text { activity recorded over time }\end{array}$ & & $\begin{array}{c}\mathrm{F}(4,10)=61.87 \\
P<0.001\end{array}$ & $\begin{array}{c}\mathrm{F}(4,10)=126.90 \\
P<0.001\end{array}$ & & \\
\hline
\end{tabular}

Lysozyme activity was assayed using the zone of inhibition test against $M$. lysodeikticus and expressed in terms of $\mu \mathrm{g} \mathrm{HEWL} / \mathrm{mg}$ protein. Means $\pm \mathrm{SD} ; \mathrm{n}=3$. For a given treatment, means in rows with the same superscript letter are similar (insignificantly different; $P>0.05$ ) whereas, those with different letters are significantly different; $P<0.05$ ). ND - not recorded. 
effect of LPS is uncertain because relatively crude preparations of these molecules were used in the present study (Table 1) and previous reports have indicated it is an elicitor (Kaneko et al., 2004); whereas highly purified LPS has little or no effect (Leulier et al., 2003; Kaneko et al., 2004).

In contrast, both the polymers $\beta$-1,3-glucan laminarin and $\beta$-1,4-glucan chitin have no obvious eliciting effect. Also, the injection of saline did not affect the level of lysozyme activity, which excludes a spiking effect and regulatory mechanisms associated with the wounding and disintegration of the epidermis, as previously reported for the pro-phenoloxidase cascade (Cerenius \& Söderhäll, 2004).

Time course of the increase in the activity of lysozyme

There was a change over time in the level of lysozyme activity in the haemolymph of $5^{\text {th }}$ instar $S$. gregaria following injection with $E$. coli (Fig. 3). The maximum level of activity was recorded $6 \mathrm{~h}$ post injection. The induced level was maintained for between 6 and $12 \mathrm{~h}$ and then declined to the constitutive level $72 \mathrm{~h}$ post injection. This may indicate that the duration of the elicitor effect only lasts for this interval of time. In B. mori (Abraham et al., 1995) and Spodoptera litura (Kim \& Yoe, 2003) it is reported that lysozyme activity reaches a maximum at 48 $\mathrm{h}$ and is slightly lower $72 \mathrm{~h}$ post injection. In G. mellonella immunized with LPS, however, the maximum lysozyme activity is attained $24 \mathrm{~h}$ post injection (Fiolka, 2008). Therefore, it is important to conduct further research on lysozyme activity in $S$. gregaria.

\section{Site of production}

As potential sites for the biosynthesis of lysozyme, its activity was determined separately in haemocytes, fat body and mid gut tissue of $5^{\text {th }}$ instar $S$. gregaria (and the activity level was considered to correspond to its rate of synthesis, neglecting the rate of release into the haemolymph) before and after an immunological challenge with E. coli (Table 2). The data show that before the challenge, the lysozyme is constitutively synthesized at comparatively low levels in both haemocytes and fat body, but not in mid gut tissue. After the challenge, the time-course in the level of activity of lysozyme in these two tissues is similar to that recorded in haemolymph plasma.

Haemocytes and fat body are the two main immunityconferring tissues, which are collectively responsible for the production and secretion of antimicrobial agents (Tsakas \& Marmaras, 2010). Also, they are the main sites of lysozyme synthesis and secretion (Zhang et al., 2009). The results indicate that the level of lysozyme activity in haemocytes is higher than in the fat body of $5^{\text {th }}$ instar $S$. gregaria (Table 2). This may also be the case for lysozyme activity in hemimetabolous insects such as $L$. migratoria (Zachary \& Hoffmann, 1984), Rhodnius prolixus (Azambuja et al., 1999), Teleogryllus commodus (Drayton \& Jennions, 2011) and other AMPs (Bulet \& Stöcklin, 2005).

Lysozymes are also recorded in the pericardial cells of M. sexta (Russell \& Dunn, 1990), mid gut of several Di- ptera, such as, Anastrepha fraterculus (Lemos \& Terra, 1991), Drosophila melanogaster (Kylsten et al., 1992; Daffre et al., 1994) and Musca domestica (Lemos \& Terra, 1991; Cançado et al., 2008), salivary glands of Anopheles darlingi (Moreira-Ferro et al., 1998), D. melanogaster (Kylsten et al., 1992), Helicoverpa zea (Liu et al., 2004), Reticulitermes speratus (Fujita et al., 2002) and eggs of Anthonomus grandis (Ourth \& Jones, 1980) and Ceratitis capitata (Fernandez-Sousa et al., 1977).

A comparison of the lysozyme activity in plasma and in haemocytes at two successive intervals following an immunological challenge (Table 2) revealed that it is lower in the plasma than haemocytes between 6-24 h. This is also recorded for other hemimetabolous insects such as L. migratoria (Zachary \& Hoffmann, 1984) and Blaberus discoidalis (Wilson \& Ratcliffe, 2000). Later, i.e. $48-72 \mathrm{~h}$ post-challenge, the level of lysozyme activity in both haemocytes and plasma was similar, possibly due to pooling in the plasma of lysozyme from different tissues and probably also to a decline in the level of synthesis in haemocytes; and the level recorded in un-challenged insects was similar to that recorded $72 \mathrm{~h}$ post-challenge (Table 2). It is possible that the level of lysozyme activity recorded in plasma is an over-estimate of the actual level in vivo, because a small degree of lysis certainly occurred due to the fragility of the haemocytes.

In summary, S. gregaria has a constitutive level of lysozyme activity and the de novo induction of its biosynthesis in haemocytes, fat body and probably other body tissues follows a signal transduction mechanism when the associated molecular patterns of the PGN and LPS of an invading pathogen are recognized. The induced increase in the level of activity of lysozyme reached a maximum within the first few hours of a pathogen being recognized and then decreased to the constitutive level after $72 \mathrm{~h}$. There was no evidence to indicate that these responses were a result of regulatory mechanisms associated with wounding of the epidermis and disintegration of cells or even a spiking effect.

\section{REFERENCES}

Abraham E.G., Nagaraju J., Salunke D.M., Gupta H.M. \& DutTA R.K. 1995: Purification and partial characterization of an induced antibacterial protein in the silkworm, Bombyx mori. - J. Invert. Pathol. 65: 17-24.

Adamo S.A. 2004: Estimating disease resistance in insects: phenoloxidase and lysozyme-like activity and disease resistance in the cricket Gryllus texensis. - J. Insect Physiol. 50: 209-216.

Adamo S.A., RoberTs J.L., Easy R.H. \& Ross N.W. 2008: Competition between immune function and lipid transport for protein apolipophorin III leads to stress-induced immunosuppression in crickets. - J. Exp. Biol. 211: 531-538.

ANDERSON R.S. \& CooK M.L. 1979: Induction of lysozyme-like activity in the hemolymph and hemocytes of an insect, Spodoptera eridania. - J. Invert. Pathol. 33: 197-203.

Azambuja P., Feder D., Mello C.B., Gomes S.A.O. \& Garcia E.S. 1999: Immunity in Rhodnius prolixus: Trypanosomatidvector interactions. - Mem. Inst. Oswaldo Cruz (Rio de Janeiro) (Suppl. 1) 94: 219-222. 
BANG I.S. \& YoE S.M. 2005: Purification and cDNA cloning of lysozyme II from cabbage butterfly, Artogeia rapae larvae. Entomol. Res. 35: 207-211.

Boman H.G. 1994: Assaying antimicrobial peptides. In Marsh J. \& Goode J.A. (eds): Antimicrobial Peptides. Ciba Foundation Symposium 186. John Wiley and Sons, New York, pp. 54-61.

BRADFORD M.M. 1976: A rapid and sensitive method for the quantitation of microgram quantities of protein utilizing the principle of protein-dye binding. - Anal. Biochem. 72: 248-254.

Bulet P. \& StÖCKLIN R. 2005: Insect antimicrobial peptides: structures, properties and gene regulation. - Protein Pept. Lett. 12: 3-11.

Callewaert L. \& Michiels C.W. 2010: Lysozymes in the animal kingdom. - J. Biosci. 35: 127-160.

Cançado F.C., Chimoy Effio P., Terra W.R. \& Marana S.R. 2008: Cloning, purification and comparative characterization of two digestive lysozymes from Musca domestica larvae. Braz. J. Med. Biol. Res. 41: 969-977.

Cerenius L. \& SöDerhall K. 2004: The prophenoloxidaseactivating system in invertebrates. - Immunol. Rev. 198: 116-126.

Chapelle M., Girard P.A., Cousserans F., Volkoff N.A. \& Duvic B. 2009: Lysozymes and lysozyme-like proteins from the fall armyworm, Spodoptera frugiperda. - Mol. Immunol. 47: 261-269.

Daffre S., Kylsten P., Samakovlis C. \& Hultmark D. 1994: The lysozyme locus in Drosophila melanogaster: an expanded gene family adapted for expression in the digestive tract. - Mol. Gen. Genet. 242: 152-162.

Drayton J.M. \& JenNions M.D. 2011: Inbreeding and measures of immune function in the cricket Teleogryllus commodus. Behav. Ecol. 22: 486-492.

Erler S., Popp M. \& Lattorff H.M.G. 2011: Dynamics of immune system gene expression upon bacterial challenge and wounding in a social insect (Bombus terrestris). - PLoS ONE 6: e18126.

Fernandez-Sousa J.M., Gavilanse J.G., Municio A.M., PerezArando A. Rodriguez R. 1977: Lysozyme from the insect Ceratitis capitata eggs. - Eur. J. Biochem. 72: 25-33.

FIOLKA M.J. 2008: Immunosuppressive effect of cyclosporine A on insect humoral immune response. - J. Invert. Pathol. 98: 287-292.

FIOLKA M.J. 2012: Immunotoxic action of cyclosporine A on the humoral immune response of Galleria mellonella pupae. Invert. Surv. J. 9: 82-88.

Fiolka M.J., Ptaszynska A.A. \& Czarniawski W. 2005: Antibacterial and antifungal lysozyme-type activity in Cameraria ohridella pupae. - J. Invert. Pathol. 90: 1-9.

Fujimoto S., Toshimori-Tsuda I., Kishimoto K., Yamano Y. \& Morishima I. 2001: Protein purification, cDNA cloning and gene expression of lysozyme from eri-silkworm. Samia cynthia ricini. - Comp. Biochem. Physiol. (B) 128: 709-718.

Funita A., Minamoto T., Shimizu I. \& Abe T. 2002: Molecular cloning of lysozyme-encoding cDNAs expressed in the salivary gland of a wood-feeding termite, Reticulitermes speratus. - Insect Biochem. Mol. Biol. 32: 1615-1624.

Galanos C., Lüderitz O. \& Westphal O. 1979: Preparation and properties of a standardized lipopolysaccharide from Salmonella abortus equi (Novo-Pyrexal). - Zentbl. Bakteriol. Orig. (A) 243: 226-244.

Gillespie J.P., Koshinsky H.A. \& Khachatourians G.G. 1993: The occurrence of inducible anti-Escherichia coli activity in hemolymph from the migratory grasshopper, Melanoplus sanguinipes. - Comp. Biochem. Physiol. (C) 104: 111-115.
Gillespie J.P., Kanost M.R. \& Trenczek T. 1997: Biological mediators of insect immunity. Annu. Rev. Entomol. 42: 611-643.

HofFMANN D. 1980: Induction of antibacterial activity in the blood of the migratory Locust Locusta migratoria L. $-J$. Insect Physiol. 26: 539-549.

HoffmanN D. \& BRehelin M. 1976: Sur l'origine et le rôle d'une activité de type lysozyme mise en évidence dans le sang de Locusta migratoria migratorioides. - Acrida 5: 181-188.

Hultmark D. 1996: Insect lysozymes. In Jollès P. (ed.): Lysozymes: Model Enzymes in Biochemistry and Biology. Birkhauser, Basel, pp. 87-102.

Jiang H., Vilcinskas A. \& Kanost M.R. 2011: Immunity in lepidopteran insects. - Adv. Exp. Med. Biol. 708: 181-204.

JoLLÈs P. \& Jollès J. 1984: What's new in lysozyme research? Always a model system, today as yesterday. - Mol. Cell. Biochem. 63: 165-189.

Kajla M.K., Andreeva O., Gilbreath T.M. \& Paskewitz S.M. 2010: Characterization of expression, activity and role in antibacterial immunity of Anopheles gambiae lysozyme c-1. Comp. Biochem. Physiol. (B) 155: 201-209.

Kaneko T., Goldman W.E., Mellroth P., Steiner H., Fukase K., Kusumoto S., Harley W., Fox A., Golenbock D. \& SilVERMAN N. 2004: Monomeric and polymeric gram-negative peptidoglycan but not purified LPS stimulate the Drosophila IMD pathway. - Immunity 20: 637-649.

Kanost M.R., DaI W. \& Dunn P.E. 1988: Peptidoglycan fragments elicit antibacterial protein synthesis in larvae of Manduca sexta. - Arch. Insect Biochem. Physiol. 8: 147-164.

KIM J.W. \& YoE S.M. 2003: Purification of lysozyme from hemolymph of tobacco cutworm, Spodoptera litura. Korean J. Entomol. 33: 287-291.

Kylsten P., Kimbrell D.A., Daffre S., Samakovlis C. \& HultMARK D. 1992: The lysozyme locus in Drosophila melanogaster: different genes are expressed in midgut and salivary glands. - Mol. Gen. Genet. 232: 335-343.

LECOQ M. 2004: Vers une solution durable au problème du Criquet pèlerin? Sécheresse 15: 217-224.

LEE W.J. \& BREY P.T. 1995: Isolation and characterization of the lysozyme-encoding gene from the silkworm Bombyx mori. - Gene 161: 199-203.

Lemaitre B. \& Hoffmann J. 2007: The host defense of Drosophila melanogaster. - Annu. Rev. Immunol. 25: 697-743.

Lemos F.J.A. \& TerRA W.R. 1991: Digestion of bacteria and the role of midgut lysozyme in some insect larvae. - Comp. Biochem. Physiol. (B) 100: 265-268.

Leulier F., Parquet C., Pili-Floury S., Ryu J.H., Caroff M., Lee W.J., Mengin-Lecreulx D. \& Lemaitre B. 2003: The Drosophila immune system detects bacteria through specific peptidoglycan recognition. - Nat. Immunol. 4: 478-484.

Liu F., Cui L., Cox-Foster D. \& Felton G.W. 2004: Characterization of a salivary lysozyme in larval Helicoverpa zea. $-J$. Chem. Ecol. 30: 2439-2457.

Lomer C.L., Bateman R.P., Johnson D.L., Langewald J. \& Thomas M.B. 2001: Biological control of locusts and grasshoppers. - Annu. Rev. Entomol. 46: 667-702.

Maeno K. \& TAnaka S. 2008: Phase-specific developmental and reproductive strategies in the desert locust. - Bull. Entomol. Res. 98: 527-534.

Marmaras V.J. \& Lampropoulou M. 2009: Regulators and signalling in insect haemocyte immunity. - Cell Signal. 21: 186-195.

Mohrig W. \& Messner B. 1968: Lysozyme as antibacterial agent in honey and bees venom. - Acta Biol. Med. Ger. 21: 85-95. 
Moreira-Ferro C.K., Daffre S., James A.A. \& Marinotti O. 1998: A lysozyme in the salivary glands of the malaria vector Anopheles darlingi. - Insect Mol. Biol. 7: 257-264.

Morishima I., Horiba T., IKetami M., Nishioka E. \& Yamano Y. 1995: Parallel induction of cecropin and lysozyme in larvae of the silkworm Bombyx mori. - Dev. Comp. Immunol. 19: 357-363.

Ourth D.D. \& Jones B.R. 1980: Lysozyme in eggs of the cotton boll weevil, Anthonomus grandis Boheman (Coleoptera: Curculionidae). - Experientia 36: 196.

Park H.Y., Park S.S., Shin S.W., Park D.S., Kim M.G., OH H.W. \& Joo C.K. 1997: Protein purification and nucleotide sequence of a lysozyme from the bacteria-induced larvae of the fall webworm, Hyphantria cunea. - Arch. Insect Biochem. Physiol. 35: 335-345.

Park J.W., Kim C.H., Kim J.H., Je B.R., Roh K.B., Kim S.J., Lee H.H., Ryu J.H., Lim J.H., Oh B.H., Lee W.J., Ha N.C. \& Lee B.L. 2007: Clustering of peptidoglycan recognition protein-SA is required for sensing lysine-type peptidoglycan in insects. - Proc. Natl. Acad. Sci. USA 104: 6602-6607.

Powning R.F. \& DAvidson W.J. 1973: Studies on insect bacteriolytic enzymes: I. Lysozyme in haemolymph of Galleria mellonella and Bombyx mori. - Comp. Biochem. Physiol. (B) 45: 669-681.

Russell V.W. \& DunN P.E. 1990: Lysozyme in the pericardial complex of Manduca sexta. - Insect Biochem. 20: 501-509.

Russell V.W. \& DunN P.E. 1991: Lysozyme in the midgut of Manduca sexta during metamorphosis. - Arch. Insect Biochem. Physiol. 17: 67-80.

SCHNEIDER P.M. 1985: Purification and properties of three lysozymes from hemolymph of the cricket, Gryllus bimaculatus (De Geer). - Insect Biochem. 15: 463-470.

Shelby K.S., Cui L. \& WebB B.A. 1998: Polydnavirus-mediated inhibition of lysozyme gene expression and the antibacterial response. - Insect Mol. Biol. 7: 265-272.
SRYGLeY R.B. \& LoRCH P.D. 2011: Weakness in the band: Nutrient mediated trade-offs between migration and immunity of Mormon crickets, Anabrus simplex. - Anim. Behav. 81: 395-400.

Sumida M., Ichimori H., Yuhki T., Mori H. \& Matsubara F. 1992: Induction of antibacterial activity in the haemolymph of the silkworm, Bombyx mori, by injection of formalintreated Escherichia coli $\mathrm{K}-12$ in the anterior and posterior body part of the ligated larvae. - Comp. Biochem. Physiol. (B) 101: 173-178.

TSAKAS S. \& Marmaras V.J. 2010: Insect immunity and its signalling: an overview. - Invert. Surv. J. 7: 228-238.

Vocadlo D.J., Davies G.J., Laine R. \& Withers S.G. 2001: Catalysis by hen egg-white lysozyme proceeds via a covalent intermediate. - Nature 412: 835-838.

Wang W.X., Wang Y.P., Deng X.J., Dang X.L., Tian J.H., YI H.Y., LI Y.F., He X.F., CAO Y., XIA Q.Y., LAI R., WEN S.Y. \& PAskowitz S. 2009: Molecular and functional characterization of a c-type lysozyme from the Asian corn borer, Ostrinia furnacalis. - J. Insect Sci. 9: 17-29.

Wilson R. \& RAtcliffe N.A. 2000: Effect of lysozyme on the lectin-mediated phagocytosis of Bacillus cereus by haemocytes of the cockroach, Blaberus discoidalis. - J. Insect Physiol. 46: 663-670.

ZACHARY D. \& HoFFMANN D. 1984: Lysozyme is stored in the granules of certain hemocyte types in Locusta. - J. Insect Physiol. 30: 405-411.

Zhang Y., Huang J., Zhou B., Zhang C., Liu W., Miao X. \& HuANG Y. 2009: Up-regulation of lysozyme gene expression during metamorphosis and immune challenge of the cotton bollworm, Helicoverpa armigera. - Arch. Insect Biochem. Physiol. 70: 18-29.

Received November 8, 2012; revised and accepted April 18, 2013 